\title{
THE UNTIMELY TOMB: DEATH IN THE SPIRITUALITY OF THE DESERT DANIEL LEMENI
}

\author{
UDC: $27-788$ "03/05" \\ 27-35"03/05" \\ Review \\ Manuscript received: 22. 10. 2016 \\ Revised manuscript accepted: 07. 02. 2017. \\ DOI: 10.1484/J.HAM.5.113743
}

\author{
D. Lemeni \\ West University of Timișoara \\ Faculty of Teology \\ Str. Intrarea Sabinei, nr.1, ap. 6 \\ 300422 Timişoara, Timiş, Romania \\ dlemeni@yahoo.com
}

In this paper we will explore the "practice of death" in the spirituality of the desert. The paper is divided into two sections. Section 1 explores the desert as place of the death. The monk has symbolized this death by locating his existence in the desert, because the renunciation of secular life led the monk to regard himself as dead. Section 2 points out depictions of monks as dead or entombed. We will examine here the role played by "daily dying" in the Life of Antony. Antony the Great characterizes his life as a kind of "death", because he lives as though dying each day. In other words, the monk, though not actually dead, effectively dies each day. This kind of "death" (daily dying) contains the seeds of later ascetic tradition on a "practice of death".

Keywords: death, Desert Fathers, Late Antiquity, monasticism, Antony the Great.

\section{INTRODUCTION}

The withdrawal from the world is the most powerful metaphor to describe the mortification in the spirituality of the desert. In the early ascetic literature (especially, the Sayings of the Desert Fathers and The Life of Antony), the Christian monk has long been regarded as a metaphor of „death" because for him the desert was a place of burial. In this paper, we will explore the meaning of the "death" to the Desert Fathers (Section 1), and the meaning of the "daily dying" in the Life of Antony (Section 2).

Generally, this paper sets out two tasks. First, it shows how the spirituality of the desert is imbued with the practice of death. Second, by examining the ways in which Desert Fathers engaged with death we will point out more clearly the models in which this spirituality took or perhaps was given shape as a normative body of wisdom.

\section{DEATH AMONG THE DESERT FATHERS}

The period from the third to the fifth centuries of Late Antiquity witnessed one of the most extraordinary movements in Christian history ${ }^{1}$. Thousands of people in Egypt and other parts of the eastern Mediterranean took themselves off to the desert to live as hermits. As Douglas Burton-Christie has remarked "the retreat to the desert and growth of monasticism in fourth-century Egypt has long been recognized as one of the most significant and alluring moments of early Christianity. In the withdrawal from the mainstream of society and culture to the stark solitude of the desert, a vibrant and original spirituality was born which had a wide influence on both contemporaries and succeeding generations"2.

Therefore, the way of the desert, more than any other movement in the history of Christendom, has been associated with wilderness or physical withdrawal (anachoresis) ${ }^{3}$. The ascetic's gesture - often expressed as a willingness to leave behind the usual patterns of their relationships, activities, and responsibilities - was dramatic and compelling and signaled in clear, unambiguous terms a shift of allegiance from "the world" to "the kingdom of heaven". The insistence on the physical desert setting as most beneficial for ascetic life was one of the essential features of the Egyptian asceticism. The word ,desert' refers not only to a physical place, but, in the words of Tim Vivian, this concept „takes on two additional levels of meaning: the spiritual and the mystical. Not only was the desert a religious place, it signified a spiritual way of being"4. The desert of the monk was charged with significance, not as an isolated place, but as part of a complex social and geographical network of meaning 5 .

In this section we consider the desert as a "disposition" of detachment from the world and "bodily desire", a way

\footnotetext{
${ }^{1}$ For the desert movement, see A. RYRIE, The Desert Movement: Fresh Perspectives on the Spirituality of the Desert, Norwhich, 2011.

${ }^{2}$ D. BURTON-CHRISTIE, The Word in the Desert: Scripture and the Quest for Holiness in Early Christian Monasticism, Oxford, 1993 , p. 3.

${ }^{3}$ As K. WARE notes, Anachoresis is one of the two axiomatic elements of ascetic practice [cf. The Way of the Ascetic: Negative or Affirmative?, in V.L. Wimbush, R. Valantasis (eds.), Asceticism, Oxford, 1998, p. 3-15, here, p. 4-5]. For more details on this subject, see J.E. GOEHRING, Ascetics, Society, and the Desert. Studies in Early Egyptian Monasticism, Harrisburg, PA, 1999.

${ }_{4}^{4}$ T. VIVIAN, Introduction, in Paphnutius. Histories of the Monks of Upper Egypt, trans. by T. Vivian, Kalamazoo, 200o, p. 23.

${ }^{5}$ On the concrete character as well as the symbolic meaning of the monk's dwelling place, see C.T. SCHROEDER, 'A Suitable Abode for Christ': The Church Building as Symbol of Ascetic Renunciation in Early Monasticism, in Church History, 73, 3, 2004, p. 472-521; D. BROOKS-HEDSTROM, The Geography of the Monastic Cell in Early Egyptian Monastic Literature, in Church History, 78, 4, 2009, p. 756-791; IDEM, Divine Architects: Designing the Monastic Dwelling Place, in R. Bagnall (ed.), Egypt in the Byzantine World, 300-700, Cambridge, 2007, p. 368-389.
} 
in which ascetics strove to "die to the world". More exactly, we will trace here "practice of death" as it emerges in the Sayings of the Desert Fathers. From this perspective, a special emphasis is placed on the importance of the desert - a symbol of total withdrawal and rejection of the world - as a training ground for those who aspire to spiritual progress.

Let us begin with the following story from the Apophtegmata Patrum: "A brother visited Abba Macarius the Egyptian and said to him: 'Abba, tell me a saying (indicating) how I can be saved'. The elder said: 'Go to the tomb and insult the dead', so the brother went. He insulted and stoned (them) then he came and told the elder. 'And they said nothing to you?' he said to him. 'No', said (the brother). The elder said to him: 'Go again tomorrow and praise them'. The brother went and praised them, saying: 'Apostles, holy and righteous ones', then he came to the elder and told him: 'I praised (them)'. 'And they made no response?', he said to him. 'No', said the brother, and the elder said to him: 'You know how much you insulted them and they gave no answer; and how much you praised them but they said nothing to you. So too must you become dead if you want to be saved. Pay no attention (like the dead) either to the injustice of folk or to their praise - then you can be saved"'6.

In this case, the ascetic had to become as one dead, immune to insult and praise. Essentially, the true monk is impassive, unresponsive and unmoved by any provocation, because he is like a dead man. An anonymous elder in Palestine rebuked two visiting philosophers, saying "Let the object of your philosophy be always to contemplate death, possessing yourselves in silence and tranquility"7.

This state of apatheia ${ }^{8}$ is to be as unmoved by injury or flattery as the dead. Therefore, the life of desert led the monk to regard himself as dead 9 . This had an impact on his relationships with others in that he would refuse to engage in their affairs. For example, the following apophtegm illustrates the interior meaning of this "death": Abba Poemen would not allow Anoub to invite priests visiting the monasteries to see them, explaining: "This has nothing to do with me, for I am dead and a dead person does not speak. They are not to think that I am in here with them" ${ }^{\prime \prime}$. While this may have been a humble refusal to engage in matters that did not concern him, it is more likely that Poemen discerned that it would lead to futile conversation that would damage his purity and theirs. Just how thoroughly dead towards others monk regarded themselves is evident in the comment that a monk should consider himself 'already three days in a tomb': "Abba Poemen said that a brother asked Abba Moses: 'In what way does a person make himself dead with respect to his neighbor?'. The elder said to him: 'Unless a person put it in his heart that he has already been three days in a tomb, he cannot attain to this saying" ". The "dead" monk both cultivates an interior tranquility that isolates him from distractions and temptations, and he takes care how he relates to others.

In another saying, we find this facet of ascetic death: "Abba Daniel said of Abba Arsenius that there once came to him an officer (a military messenger) bringing him the testament of some senator related to him who had left him an exceedingly large inheritance. He took it and would have torn it up, but the officer fell at his feet, saying: 'Do not tear it up I beseech you since my head will be struck off'. Abba Arsenius said to him: 'I died before he did just now', and he sent it back, accepting nothing" ${ }^{12}$. Since a dead person can have no legal rights, this indicates that the monk's sense of being dead was a new way of conceiving relationships. The Desert Fathers have promoted a kind of non-divisive relationships, because the dead person has no relatives ${ }^{13}$. These kinds of claims are not to be confused with denigration of marriage or families ${ }^{14}$. The ascetic may deny his blood family, but he certainly has an ecclesial and monastic family in his 'brothers' and abbas ${ }^{15}$.

In other words, the desert represented, in symbol and practice, a complete and utter dependence on God alone. The withdrawal involved breaking the ties with one's family, because Desert Fathers had no family, and belonged only to God $^{16}$. The first and foremost concern of the monk was to maintain his state of mental tranquility and detachment or spiritual death. For this reason, Antony politely refused the invitation of a military commander to extend his visit, since he knew full well that he would quickly suffocate in such unaccustomed surroundings: "Just as fish perish when they lie exposed for a while on the dry land, so also the monks relax their discipline when they linger and pass time with you. Therefore, we must rush back to the mountain, like the

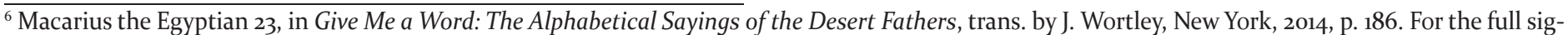
nificance of the cultivation of indifference in the desert, see Detachment, in J. KELLENBERGER, Dying to Self and Detachment, Farnham, 2012, p. 35-50, and The Power of Detachment, in J. CHRYSSAVGIS, In the Heart of the Desert: The Spirituality of the Desert Fathers and Mothers, Bloomington, 2008, p. 69-74. 7 The Spiritual Meadow (Pratum Spirituale) 156, trans. by J. WORTLEY, 1992, Kalamazoo, 1992, p. 130.

${ }^{8}$ For the death to self or monastic apatheia, see J.L. ZECHER, The Role of Death in the Ladder of Divine Ascent and the Greek Ascetic Tradition, Oxford, 2015, p. 124-125.

9 For the desert as a symbol of death, see J.E. GOEHRING, The World Engaged: The Social and Economic World of Early Egyptian Monasticism, in IDEM, op. cit. (n. 3), p. 39-52.

${ }^{10}$ Poemen 3 (trans. by J. Wortley), p. 224.

${ }^{\text {" Moses }} 12$ (trans. by J. Wortley), p. 196. On the metaphor of death in Apophtegmata Patrum, see G. GOULD, The Desert Fathers on Monastic Community, Oxford, 1993, p. 132-138.

${ }^{12}$ Arsenius 29 (trans. by J. Wortley), p. 47.

${ }^{13}$ Cf. Poemen 33 (trans. by J. Wortley), p. 233.

${ }^{14}$ See, E.A. CLARK, Anti-familial Tendencies in Ancient Christianity, in Journal of the History of Sexuality, 5, 3, 1995, p. 356-80.

${ }^{15}$ For more details on this subject, see C. RAPP, Brother-Making in Late Antiquity and Byzantium. Monks, Laymen, and Christian Ritual, Oxford, 2016; M. Chiara Giorda, F. Sbardella (ed.), Famiglia monastica. Prassi aggregative di isolamento, Bologna, 2012; G. GOULD, op. cit. (n. 11), and V. VUOLANTO, Ascetics and the Family of Christ: Metaphors, Family Dynamics and Continuity, in IDEM, Children and Asceticism in Late Antiquity: Continuity, Family Dynamics and the Rise Christianity, London - New York, 2015, p. 69-8o.

${ }^{16} \mathrm{Cf}$. Poemen 76 (trans. by J. Wortley), p. 240.
} 
fish to the sea - so that we might not, by remaining among you, forget the things within us"17.

For similar reasons, Antony the Great declined an invitation from the emperor Constantius to come him in Constantinople, after his disciple Paul had reminded him: "If you go, you will be called Antony; if you do not go, Abba Antony"18. In the spirituality of the desert, the complete inner detachment is understood as metaphor of death. This metaphor is especially prominent in some sayings attributed to Abba Moses, one of the more colorful figures in the Sayings of the Desert Fathers. Thus, Moses the Robber points out the exterior meaning of ascetic death: "A brother asked Abba Moses: 'I see something before me and am not able to grasp it'. The elder said to him: 'Unless you become dead like those in graves you will not be able to grasp it"'19. Abba Moses said: "A person must die with respect to his companion in order not to judge him in anything" ${ }^{20}$. He also said: "A person must mortify himself with respect to every evil matter before departing from the body, so that he wrongs nobody" ${ }^{21}$.

Therefore, the renunciation of secular life led the monk to regard himself as dead. As Jonathan L. Zecher has remarked, "ascetics began to make death a constant companion and to shape their own selves around it" ${ }^{22}$. And indeed, the Desert Fathers embraced their mortality; they were comfortable with death.

From this perspective, it is not unusual to hear certain Desert Fathers speak of the monk as one dead: Paesios, the brother of Abba Poemen, maintained contact with some people outside his cell, and Poemen tells Ammonas that because of it 'I have no repose'. Ammonas said to him: 'Go, remain in your cell and put it into your heart that you have already been a year in the tomb ${ }^{23}$. Finally, the metaphor of death serves only to emphasize the detachment of monks from the secular world, and especially from material possessions: "There was a monk living in a cave in the desert. It was communicated to him by his relatives in the flesh: 'Your father is gravely ill and is going to die: come so you can inherit from him,' but he answered them: 'I died to the world before him; a dead man does not inherit from one who is alive"24. This monk went to die before his death, to renounce 'his own life'. In other words, a monk should not allow himself to be adversely affected by the behavior of others, which is no business of his.

In fact, in Apophtegmata Patrum life can only be understood from the perspective of death: Abba Theophilus of
Alexandria at the point of death, said "Blessed are you, Abba Arsenius, for you were ever mindful of this hour" 25 . Theophilus, the archbishop attempts here to delimit what mode of life should be cultivated in light of death. In other words, he sets up an art of dying, a lifestyle defined by renunciation and virtue, respectively, of ascetic life. The contours of this lifestyle mark out a monastic "art of dying". In this context, it is not hard to see how the asceticism is the inauguration of a new self ${ }^{26}$, and "choosing death" could be as an ascetic strategy. Consciousness of death means also dwelling on mortality: "Closing your tomb", says one of the Desert Fathers, "as though you were already dead, so that all the time you are thinking your death is at hand" ${ }^{27}$.

In other words, when monk has completely renounced the world, he dwells in sight of death for live a new of life. To live entirely within each day, bounded by mortality, dramatically illustrates the sort of "newness of life" that ascetics sought. Each day offers the monk a chance to constant renewal, the hope of a new beginning. As Jonathan Zecher has noted, "each day brings the opportunity of beginning once more - which is the sum total of progress for which monastics longed"28. Finally, each day offers the monk to constantly begin again, to work urgently and tirelessly, since his life becomes a kind of ne lifetime. This intertwining of sober reflection, life, and death, will deeply inform Egyptian and Desert Fathers' thinking.

\section{THE ROLE OF DEATH IN THE LIFE OF ANTONY}

As we have seen above, the ascetic literature of the late fourth and fifth centuries reflects a sustained interest in making meaning and function of death in monastic practice. The issues implicated in the late ancient discourse of ascetic ideals and practices would create a space for interpretation of death as an ascetic spiritual exercise. In this regard the ascetic "death" resembles the 'spiritual exercises' which Pierre Hadot discerns among philosophers. Pierre Hadot discussed at some length the practice of so-called 'spiritual exercises' in antiquity, arguing that Christian ascetical practices owed much to these ${ }^{29}$.

Therefore, the practice of askesis, the life of austerity and self-discipline in pursuit of spiritual growth, traces its roots back to the dawn of antiquity. The Christian ascetic ideals emerged against a background of Graeco-Roman philosophy ${ }^{30}$. A strong link between ascetic practice and spiritual exercises was introduced by Mark Sheridan, which

${ }^{17}$ Life of Anthony 85, trans. by R.C. Gregg, New York, 1980, p. 93.

${ }^{18}$ Anthony 31 (trans. by J. Wortley), p. 38.

${ }_{19}$ Moses 11 (trans. by J. Wortley), p. 196.

${ }^{20}$ Moses 14 (trans. by J. Wortley), p. 197.

${ }^{21}$ Moses 1.05 (trans. J. Wortley), p. 197.

${ }^{22}$ J.L. ZECHER, op. cit. (n. 8), p. 104.

${ }_{23}$ Poemen 2 (trans. J. Wortley), p. 224.

${ }^{24}$ John Cassian 8 (trans. by J. Wortley), p. 167.

${ }^{25}$ Theophilus of Alexandria 5 (trans. by J. Wortley), p. 82.

${ }^{26}$ For the theme of ascetic self more generally, see R. VALANTASIS, The Making of the Self: Ancient and Modern Asceticism, Cambridge, 2008; R. SORABJI, Self: Ancient and Modern Insights about Individuality, Life, and Death, Oxford, 2006; G. FLOOD, The Ascetic Self: Subjectivity, Memory and Tradition, Cambridge, 2004.

${ }^{27}$ John Colobos 34 (trans. by J. Wortley), p. 139.

${ }^{28}$ J. L. ZECHER, op. cit. (n. 8), p. 111.

${ }^{29}$ P. HADOT, Exercices spirituels antique et «philosophie chrétienne», in Exercices spirituels et philosophie antique, Paris, 1981, p. 60-63.

$3^{30}$ For an introduction to pagan asceticism, see E. DIAMOND, Holy Men and Hunger Artists: Fasting and Asceticism in Rabbinic Culture, Oxford, 2004; J.A. FRANCIS, Subversive Virtue: Ascetics and Authority in the Second-Century Pagan World, University Park, PA, 1995; V.L. WIMBUSH, Ascetic Behaviour in Greco-Roman Antiquity, Minneapolis, 1990, and V.L. Wimbush, R. Valantasis (eds.), op. cit. (n. 3). 
applies Pierre Hadot's conception to Vita Antonii ${ }^{{ }^{1}}$. The spirituality of early Egyptian monasticism was based on one presupposition, namely, the possibility of progress in the spiritual life. This was closely linked to the idea of a spiritual exercise, of a combat against the passions which obstructed the road to self-transformation of the monk. In this context, we emphasize that one of the most basic and primary means of spiritual progress was "daily death" or "daily martyrdom". And indeed, of the diverse spiritual exercises which defined the quest for holiness in early monasticism, "daily dying" stands as one of the most fundamental and influential.

In this section we will point out the active expression of 'living death' in the desert. This expression is understood as 'daily death' according to which the monk dies, but not just any death. As we have seen above the monk's primary goal is a "disposition" of detachment from the world and "bodily desire", gained through asceticism. Briefly summarized, martyrdom epitomizes very well this renunciation of the world ${ }^{32}$.

As we know, asceticism was a tool to achieve spiritual growth. Hermits and monks subjected their bodies to a lifetime of ever more demanding physical rigors. The duration of their ascetic efforts set them in contrast to the martyrs whose bodily suffering was compressed into the short period of time prior to their execution. In this way, as Claudia Rapp has remarked, "those who lived the monastic life, whether in solitude or in a community, became the successors of the martyrs, once the Edict of Milan (312) had declared an end to the persecutions and thereby removed the opportunities for dramatic singular acts of martyrdom"33. Once the persecutions had come to an end, it was the monasticism ("white martyrdom") who carried on the heritage of the martyrdom ("red martyrdom").
Therefore, "although the monastic movement largely postdates this era of martyrdom, martyrs and monks became linked in the Christian imagination, with monks proclaimed as successors of the martyrs and monasticism described as a sort of daily martyrdom" 34 . At the midpoint of the Life of Antony, Athanasius explicitly marks a transition from the age of the martyrs to that of the monks. After Antony does not receive the actual martyrdom he desires and the persecutions end, Antony "departed and withdrew once again to the cell, and was there daily being martyred by his conscience, and doing battle in the contests of the faith"35. His martyrdom and contending consist of "a greater and more strenuous discipline".

In this context Antony the martyr becomes also Antony the holy $\operatorname{man}^{36}$. After the end of the persecutions, it was the ascetic holy men who subjected their bodies to daily martyrdom that were celebrated in hagiographical accounts, a literary tradition that had its beginning with the Life of Anthony, composed shortly after his death in 356 .

According to Susanna Elm, the late Roman Empire represents an era marked by increasing authorship and the development of new literary genres that "elaborated new notions of sanctity and charisma. It was the period in which models of martyrdom and confessional sainthood emerged. Through this abundance of hagiographical texts and miracle stories, the authors of this emerging culture of charisma reveal to their fellows the processes by which humans could fashion themselves into saints" 37 .

A gallery of holy men, living in monasteries or isolated cells, in tombs, or on pillars, all broadened the network of holy space. All those blessed with spiritual authority (charisma $)^{38}$, and served as a focus of divine power and delineated

${ }^{31}$ Cf. M. SHERIDAN, The Spiritual and Intellectual World of Early Egyptian Monasticism, in From the Nile to the Rhone and Beyond. Studies in Early Monastic Literature and Scriptural Interpretation, Roma, 2012 (Studia Anselmiana, 156), p. 47-88. Also, for an application of Hadot's notion of spiritual exercises to Christian monasticism, see J. DRISCOLL's thorough study on Evagrius: The Ad Monachos of Evagrius Ponticus: Its Structure and a Select Commentary, Roma, 1991 (Studia Anselmiana, 104), p. 361-384.

${ }^{32}$ For an analysis of the dynamic interaction between martyrdom and asceticism, see P. Gemeinhardt, J. Leemans (eds.), Christian Martyrdom in Late Antiquity, Berlin, 2012; J. Leemans (ed.), Martyrdom and Persecution in Late Antique Christianity: Festschrift Boudewijn Dehandschutter, Leuven, 2010; G.E.M. de Ste Croix (ed.), Christian Persecution, Martyrdom, and Orthodoxy, Oxford, 2006 and E. CASTELLI, Martyrdom and Memory: Early Christian Culture Making, New York, 2004.

${ }_{33}$ C. RAPP, Holy Bishops in Late Antiquity: The Nature of Christian Leadership in an Age of Transformation, Berkeley and Los Angeles, 2005, p. 75.

34 W. HARMLESS, Desert Christians: An Introduction to the Literature of Early Monasticism, Oxford, 2004, p. 14-15.

${ }^{35}$ Life of Anthony 47 (trans. by R.C. Gregg), p. 66. On Anthony's ascetic career see P.H. GÖRG, The Desert Fathers: Saint Anthony and the Beginnings of Monasticism, San Francisco, 2011; P. ROUSSEAU, Antony as Teacher in the Greek Life, in T. Hagg, P. Rousseau (eds.), Greek Biography and Panegyric in Late Antiquity, Berkeley, 2000, p. 92-95; S. RUBENSON, The Letters of St. Antony: Monasticism and the Making of a Saint, Minneapolis, 1995, p. 89-125; P. BROWN, The Rise and Function of the Holy Man in Late Antiquity, in The Journal of Roman Studies, 61, 1971, p. 80-101.

${ }^{36}$ The exegetical literature on the late-antique holy man is vast. For the multifaceted picture of the holy man in Late Antiquity, see especially P. BROWN, The Rise and Function of the Holy Man in Late Antiquity, in Journal of Roman Studies 61, 1971, p. 80-101; reprinted in IDEM, Society and the Holy in Late Antiquity, Berkeley, 1982, p. 103-152; now revised in IDEM, Authority and the Sacred: Aspects of the Christianisation of the Roman World, Cambridge, 1995, p. 57-78, chapter 3: "Arbiters of the Holy: The Christian Holy Man in Late Antiquity". For assessments of the evolution of Brown's view of the holy person in Late Antiquity, see S. ELM, Introduction, in Journal of Early Christian Studies, 6, 1998, p. 343-351; and see Brown's own assessment, The Rise and Function of the Holy Man in Late Antiquity, 1971-1997, in Journal of Early Christian Studies, 6, 1998, p. 353-376. The Journal of Early Christian Studies 6 (Fall 1998) is completely devoted to a re-assessment of Brown's holy man. Also, see R. KOSINSKI, Holiness and Power: Constantinopolitan Holy Men and Authority in $5^{\text {th }}$ Century, Berlin, 2016; D. CANER, The Model Holy Man, in his Wandering, Begging Monks. Spiritual Authority and the Promotion of Monasticism in Late Antiquity, Berkeley-Los Angeles-London, 2002; A. CAMERON, On defining the holy man, in J. Howard-Johnston, P.A. Hayward (eds.), The Cult of Saints in Late Antiquity and the Middle Ages. Essays on the Contribution of Peter Brown, Oxford, 1999; P. COX MILLER, Biography in Late Antiquity: A Quest for the Holy Man, Berkeley, 1983.

${ }^{37}$ S. ELM, Introduction, in Journal of Early Christian Studies, 6, 1998, p. 349.

${ }^{38}$ The nexus between asceticism and authority was examined by C. RAPP, op. cit. (n. 33). The question of the relationship between asceticism and authority is rich in nuances throughout early Christian literature. For this subject, see C. LEYSER, Authority and Asceticism from Augustine to Gregory the Great, Oxford, 2001; J. CHRYSSAVGIS, Obedience: Hierarchy and Asceticism: The Concept of Spiritual Authority in the Church, in St Vladimir's Theological Quarterly, 34, 1, 1990, p. 49-6o; P. HENRY, From Apostle to Abbot: The Legitimation of Spiritual Authority in the Early Church, in Studia patristica, 17, 2, 1982, p. 491-505; P. ROUSSEAU, Ascetics, Authority, and the Church in the Age of Jerome and Cassian, Oxford, 1978; IDEM, Spiritual Authority of the Monk Bishop: Eastern Elements in some Western Hagiography of the Fourth and Fifth Centuries, in Journal of Theological Studies, 22, 1971, p. 380-419. On individual 
a new territory of grace ${ }^{39}$. Desert Fathers were the holy men of late antiquity, monks who were endowed with special spiritual gifts of teaching, prayer, and miracle working. From this perspective, the desert - as locus of intense spiritual experience - was of crucial importance to the development of the ascetic experience.

As we have seen above, desert asceticism is seen as the successor to martyrdom. This transition is evident in the spirituality of the desert, especially in Life of Antony. Saint Antony preached a kind of daily "dying" to his disciples, because he lived always with his own death in sight. The dying Antony commanded his disciples to "live as though dying daily" 40 . Undoubtedly, the Life of Antony points out asceticism as daily "dying" made possible by deep withdrawal.

As Williams Harmless has remarked, Athanasius claims, in essence, "that Antony was inventing a new style of martyrdom, the 'daily' martyrdom of asceticism; and the athletic and military metaphors once applied to the martyrs would now be applied to Antony, that he did 'battle' in 'contests of faith" ${ }^{41}$. Here we see that monk was the successor to the martyr. Some exegetes see a very strong connection, even a typology, between martyr and ascetic ${ }^{42}$.

The ascetic life was a daily martyrdom of asceticism, a heroic substitute for the martyr, because Antony was being depicted as "daily a martyr", though the fate of actual martyrdom was something that God apparently denied him. And indeed, contrary to the traditional martyrs where death came in the end, Antony's martyrdom represented a chronic state. His very existence was a perpetual extension of the moment of dying. When Athanasius presented Antony's death as "worthy of imitation", he explicitly tied this to how one should "live as though dying daily" 33.

This new paradigm now became associated with a discipline and self-denial like a martyr's, but rather than dying in a dramatic way, it presumes a spirituality of dying daily, of letting go in surrender one day at a time. To portray ascetics as martyrs was not at all unique to Athanasius. As Christians came to power and adherents of the dominant church could no longer expect to be martyred - at least not within the borders of the empire - ascetics were increasingly presented as martyrs. As Christianity Elizabeth A. Clark notes: "The church fathers frequently asserted that asceticism was a new form of martyrdom, one in which we could be martyred daily"44. From this perspective, asceticism was a tool to achieve spiritual maturity. Desert Fathers subjected their bodies to a lifetime of ever more demanding ascetic discipline. For example, Abba Poemen believed that renunciation was the only way to reach God: "A person's will is a brazen wall (Jer $1,18)$ and an immoveable rock between him and God. If a person abandons it, he too says: 'In my God I will leap over the wall' (Ps 18,30-31). But if (self-) justification combine with the will, a person is in a bad way" 45 .

What this meant in practice for most monks was putting themselves under the direction of an elder and learning the exacting way of obedience. In this sense, Steven D. Driver said that in the desert "the basis of the teaching relationship was the absolute obedience that the disciple owed to his $a b b a "{ }^{46}$.

Desert Fathers knew from experience that the freedom and intimacy with God which they sought could come about only through renunciation of one's very self - that is the will. Abba Joseph of Thebes said there are three works "that are precious in the sight of the Lord", the most exalted was "when someone is living in submission to a spiritual father and renounces all his own desires" 47 . Abba Pambo confirmed this, indicating that poverty, in the sense of renunciation of material goods, was in fact a relative term. Renunciation of the will, on the other hand, brought one into the company of the martyrs. Four monks came one day to see him, and each revealed the virtue of his neighbor. One fasted a great deal, the other was poor, and the third had acquired great charity. The fourth "had been obedient to an elder for twenty-two years". Abba Pambo then said: "I tell you, the virtue of this last one is the greatest. Each of the others has obtained the

figures of spiritual authority, see J. W. Ddrijvers, J. W. Watt (eds.), Portraits of Spiritual Authority: Religious Power in Early Christianity, Byzantium and the Christian Orient, Leiden, 1999.

39 In Late Antiquity, the holy man transformed his territory into a sacred space and created a new site for the interrelation between society and the sacred. For this aspect of the holy man, see the contribution of M.S. BURROWS, On the Visibility of God in the Holy Man: A Reconsideration of the Role of the Apa in the Pachomian Vitae, in Vigiliae Christianae, 41, 1987, p. 11-33.

${ }^{40}$ Life of Anthony 91 (trans. by R.C. Gregg), p. 97. For this principle in the desert spirituality ("Daily Dying”), see J. L. ZECHER, op. cit. (n. 8), p. 95-102. For more details on this theme, see B. LLEWELLYN IHSSEN, John Moschos' Spiritual Meadow: Authority and Autonomy at the End of the Antique World, Farnham, 2014, p. 105-136.

${ }^{41}$ W. HARMLESS, op. cit. (n. 34), p. 66.

${ }^{42}$ R.A. MARKUS, The End of Ancient Christianity, Cambridge, 1990, p. 72. For more details, see D. BOYARIN, Dying for God: Martyrdom and the Making of Christianity and Judaism, Stanford, CA, 1999; D. BRAKKE, The New Martyr and Holy Man: Athanasius of Alexandria's Life of Antony, in IDEM, Demons and the Making of the Monk. Spiritual Combat in Early Christianity, Cambridge, Mass., 2006, p. 23-47; E.E. MALONE, The Monk and the Martyr: The Monk as the Successor of the Martyr, Washington, 1950; A.E.D. VAN LOVEREN, Once Again: 'The Monk and the Martyr'. Saint Anthony and Saint Macrina, in Studia patristica, 17, 1982, p. 528-538; M. TILLEY, The Ascetic Body and the (Un)Making of the World of the Martyr, in Journal of the American Academy of Religion, 59, 1991, p. 467-479.

${ }^{43}$ Life of Anthony 89 (trans. by R.C. Gregg), p. 95.

${ }^{44}$ E.A. CLARK, Devil's Gateway and Bride of Christ: Women in the Early Christian World, in IDEM, Ascetic Piety and Women's Faith: Essays on Late Ancient Christianity, Lewiston \& Queenston, 1986, p. 23-6o, here p. 45.

${ }^{45}$ Poemen 54 (trans by J. Wortley), p. 236.

${ }^{46}$ S.D. DRIVER, John Cassian and the Reading of Egyptian Monastic Culture, New York-London, 2002, p. 34. For the nature of the relationship between a spiritual guide ( $a b b a)$ and his disciples in the Apophtegmata Patrum, see G. GOULD, op. cit. (n. 11), especially p. 26-87; J. CHRYSSAVGIS, op. cit. (n. 6); L. REGNAULT, The Day-to-Day Life of the Desert Fathers in Fourth-Century Egypt, Petersham, Massachusetts, 1998, p. 126-138 (originally published in France under the title La vie quotidienne des Pères du Désert en Egypte au IVe siècle, Paris, 1990, and K. WARE, The Spiritual Guide in Orthodox Christianity, in IDEM, The Inner Kingdom, Crestwood, New York, 2001, p. 127-152.

${ }^{47}$ Joseph of Thebes (trans. by J. Wortley), p. 162. 
virtue he wished to acquire; but the last one, restraining his own will, does the will of another. Now it is of such men that martyrs are made" 48 .

At this point it is surely necessary to state clearly the monk had to die to all that within himself which separated him from God and to come to live completely in Christ. We can see this aspiration expressed in some questions which were put to Abba Moses. A brother came to him saying, "I see something before me and am not able to grasp it". The elder said to him, "Unless you become dead like those in graves you will not be able to grasp it"49. Another time, a brother asked Abba Moses now someone could consider himself to be "dead toward his neighbor". Moses responded: "Unless a person put it in his heart that he has already been three days in a tomb, he cannot attain to this saying"50. The question of how to "die toward one's neighbor" apparently preoccupied Abba Moses, for it figures in several of his sayings.

As Douglas Burton-Christie remarks, taken altogether, they express an allusion to Christ's burial: "the monk is called to participate in this burial. To 'become dead' in this way is an expression of one's allegiance, of where one's life is rooted" ${ }_{51}$. It seems that the tombs are meant to receive dead bodies, but not all bodies residing in them are necessarily dead. Christian ascetics who chose to live in tombs wished to cut off themselves from the civilized world. The tombs were really privileged locations, making their inhabitants more perceptive than others. John Chryssavgis has remarked this point brilliantly, saying that Desert Fathers "recognized death as another form of community, as another profound way of connection to themselves, to their neighbor and to God as the Lord of life and death" ${ }^{2}$.

\section{CONCLUSION}

The ascetic literature of the late fourth and fifth centuries reflects widespread concern about the meaning and function of death in ascetic practice. This literature (especially, Apophtegmata Patrum and Life of Antony) - the primary focus of this paper - shows that early monks were concerned with the practice of death. The conceptualization of "death" provides an evocative symbol on which Desert Fathers draw to cultivate and communicate their ideal identity as Christians in the Late Antiquity.

Therefore, the themes and imagery of death became integral to their conceptualization of the ascetic life. The ancients generally, and Desert Fathers especially, apprehended death much more vividly than do modern-day people. Our culture has developed an elaborate system of funeral arrangements designed to minimize contact with the physical reality of death. On the contrary, desert Christians in the late antiquity saw the fact of death as part of the cycle of life. For these monks, the desert was especially related to death, for it was the place of burial, the abode of the dead.

In the first section, we illustrated that the word "desert" refers not only to a physical place, but, takes an additional level of meaning: the spiritual. Thus, the withdrawal, combined with renunciation of secular world, led the monk to regard himself as dead. Briefly, the monk lives as though dead on the earth yet, so that the monk's home is his 'tomb before the tomb'. The Desert Fathers achieve something in their conception of ascetic life as "living death", so that the language of "living death" finds in the early ascetic literature its fullest expression as a landmark of monastic life that expresses the ideals of ascetic identity.

From this perspective, in the second section of this paper we showed that the meaning of daily "dying" in asceticism - as sign of ascetic accomplishment - became the monk feature in late ancient Christianity. The ascetics strove to "die to themselves" and "to the world", so that the Desert Fathers characterize their life as a kind of "death", because they live as though dying each day. In this context we have seen that the ways in which Desert Fathers praised practices of „death” recall the optimistic view of the all-loving monk painted by the Life of Antony and his "daily dying". This optimistic view is expressed by the ascetic ideal of the desert, namely the humble way of Christ: "Before all else, the monk ought to attain humble-mindedness for this is the first commandment of the Savior, saying: 'Blessed are the poor in spirit, for theirs is the Kingdom of Heaven (Mt 5,3)"' 53 .

The Desert Fathers strove to incorporate the humility of Christ into their lives, to become bearers of this humility. In other words, they teach that to die is, ultimately, to allow Christ to live within us.

\footnotetext{
${ }_{48}$ Pambo 3 (trans. by B. Ward), p. 196.

${ }^{49}$ Moses 11 (trans. by J. Wortley), p. 196.

${ }^{50}$ Moses 12 (trans. by J. Wortley), p. 196.

${ }^{51}$ D. BURTON-CHRISTIE, op. cit. (n. 2), p. 244.

${ }^{52}$ J. CHRYSSAVGIS, op. cit. (n. 6), p. 47.

53 John of The Cells 2 (trans. by J. Wortley), p. 156.
} 